\title{
Larvicidal activity of oil-resin fractions from the Brazilian medicinal plant Copaifera reticulata Ducke (Leguminosae-Caesalpinoideae) against Aedes aegypti (Diptera, Culicidae)
}

\author{
Atividade larvicida das frações do óleo-resina da planta medicinal brasileira \\ Copaifera reticulata Ducke (Leguminosae-Caesalpinoideae) \\ sobre o Aedes aegypti (Diptera, Culicidae)
}

\author{
Heloísa Helena Garcia da Silva ${ }^{1}$, Regina Geris ${ }^{2}$, Edson Rodrigues Filho ${ }^{3}$, \\ Cleonice Rocha ${ }^{4}$ and Ionizete Garcia da Silva ${ }^{1}$
}

\begin{abstract}
Oil-resin fractions from Copaifera reticulata Ducke (Leguminosae-Caesalpinoideae) were evaluated for larvicidal activity on third larval instars of Aedes aegypti, in searching for alternative control methods for this mosquito. The bioactive fractions were chemically monitored by thinlayer chromatography, ${ }^{1} \mathrm{H}$ and ${ }^{13} \mathrm{C}$ nuclear magnetic resonance and mass spectrometry. Bioassays were performed using five repetitions, at a temperature of $28 \pm 1{ }^{\circ} \mathrm{C}$, relative humidity of $80 \pm 5 \%$ and light and dark cycles of $12 \mathrm{~h}$. Mortality was indicated by darkening of the cephalic capsule after $24 \mathrm{~h}$ of exposure of the larvae to the solutions. The most active fractions were CRM $_{1-4}$ (sesquiterpenes) and CRM (labdane $_{5-7}$ diterpenes), which showed $L C_{50}$ values of 0.2 and $0.8 p p m$, respectively.
\end{abstract}

Key-words: Copaifera reticulata. Aedes aegypti. Terpenoids. Larvicidal activity.

\section{RESUMO}

A atividade larvicida das frações do óleo-resina de Copaifera reticulata Ducke (Leguminosae-Caesalpinoideae) foi avaliada em larvas de $3^{\circ}$ estádio de Aedes aegypti, na busca de alternativas para o controle desse mosquito. As frações bioativas foram monitoradas quimicamente através de cromatografia de camada delgada, analisada por ressonância magnética nuclear de bidrogênio $\left({ }^{1} \mathrm{H} e{ }^{13} \mathrm{C}\right)$ e espectrometria de massas. Os bioensaios foram realizados à temperatura de $28 \pm 1{ }^{\circ} \mathrm{C}, 80 \pm 5 \%$ de umidade relativa e fotofase de $12 \mathrm{~h}$, com cinco repetições. $\mathrm{A}$ mortalidade foi determinada através do escurecimento da cápsula cefálica, após 24 h de exposição das larvas às soluções. As frações mais ativas foram $C R M_{1-4}$ (sesquiterpenos) e CRM $M_{5-7}$ (diterpeno labdano), que mostraram os valores de $C L_{50}$ de 0,2 e 0,8ppm, respectivamente.

Palavras-chaves: Copaifera reticulata. Aedes aegypti. Terpenoides. Atividade larvicida.

Aedes aegypti (Lin), a mosquito that is disseminated around the world, has medical importance because it is a vector for dengue in Asia and for dengue and yellow fever in Africa and the Americas ${ }^{16}$. According to the World Health Organization ${ }^{27}$, around 2.5 billion people are exposed to dengue transmission risk, in the urban environment of the cosmotropical region. This problem could increase through adaptation of the mosquito to polluted water ${ }^{19}$, which could make control a big challenge in the near future.

There is still no vaccine available for dengue prevention. Dengue control has been limited to combating the vector using synthetic and biological insecticides. However, due to continuous use, the vector has become resistant to some chemical products $^{2} 391112$. This factor, allied to the growth of environmental

\footnotetext{
1. Departamento de Microbiologia, Imunologia, Patologia e Parasitologia, Instituto de Patologia Tropical e Saúde Pública da Universidade Federal de Goiás, Goiânia, G0. 2. Instituto de Química da Universidade Federal da Bahia, Salvador, BA. 3. Departamento de Química da Universidade Federal de São Carlos, São Carlos, SP. 4. Núcleo de Pesquisa em Química, Universidade Católica de Goiás, Goiânia, GO

Financial support: CNPq, FAPESP, CAPES, FINEP and FUNAPE

Address to: Dr. Ionizete Garcia da Silva. Dept ${ }^{\circ}$ de Microbiologia, Imunologia, Parasitologia e Patologia/IPTSP/UFG. Caixa Postal 131, $74001-970$ Goiânia, G0, Brasil.

Telefax: 5562 3261-2077

e-mail:ionizete@iptsp.ufg.br

Recebido para publicação em 13/12/2005

Aceito em 26/4/2007
} 
concerns about the ecological damage produced by synthetic insecticides, has motivated scientific research towards finding active products of botanical origin, and a number of species have been investigated with this purpose 6713141517202123

Our own screening of plant extracts for their larvicidal activity has revealed that Magonia pubescens St Hil (Sapindaceae) and Copaifera reticulata (Leguminosae) were the most active extracts $^{2022}$. Copaifera reticulata is a plant found in the tropical region of Latin America, with widespread distribution in the Brazilian Amazon forest, particularly in the States of Pará and Amazonas $^{8}$. It is also known as copaibeira and pau-d'oleo, and is one of the principal sources of copaiba oil-resin, which is widely exported from Brazil. Local populations in this region have been using this oil-resin as a primary therapeutic source for several ethno-pharmacological indications ${ }^{14826}$.

A study on Copaifera reticulata would therefore be expected to have great potential for finding bioactive compounds, since its extract has been shown to present good larvicidal activity. The present paper describes the activity and chemical composition of fractions derived from Copaifera reticulata against third-instar Aedes aegypti larvae.

\section{MATERIALS AND METHODS}

Plant material. Crude oil from Copaifera reticulata was obtained as an exudate from direct perforation of its trunk, in Jacundá, Pará, Brazil (October 2001). The trunk was perforated at $70 \mathrm{~cm}$ from the ground. The oil-resin exudate was collected, filtered through nylon cloth, and stored in amber flasks until use. The borehole in the plant was sealed with clay.

Extraction and separation. An oil sample (186.5g) was subjected to liquid-liquid partition with $n$-hexane and methanol (1:1), thus resulting in two extracts: hexane soluble (162.3g) and methanol soluble (22.8g). These extracts were subsequently chromatographed on silica gel CC (70-230 mesh), using $n$-hexane, dichloromethane and methanol, by means of the gradient polarity elution technique. Fractions from the hexane extract were named $\mathrm{CRH}_{1}$ to $\mathrm{CRH}_{8}$, and those from the methanol extract were named $\mathrm{CRM}_{1}$ to $\mathrm{CRM}_{8}$. The active fractions were re-chromatographed on a silica flash CC (230-400 mesh), using an $n$-hexane, ethyl acetate and methanol gradient. The fractions were analyzed by thin layer chromatography (TLC) using sulfuric acid solution of vanillin as the revealing reagent. Fractions with similar TLC patterns (retention factor) were combined for subsequent bioassays.

Analyses of bioactive subfractions. The bioactive subfractions were monitored by TLC and analyzed by ${ }^{1} \mathrm{H}$ nuclear magnetic resonance $\left({ }^{1} \mathrm{H}\right.$ NMR) in a Bruker ARX-200 spectrometer, using deuterated chloroform $\left(\mathrm{CDCl}_{3}\right)$ as the solvent and tetramethylsilane (TMS) as the internal standard. The non-polar fractions (from the hexane extract) were analyzed by gas chromatography coupled to mass spectrometry (GC-MS), using electron impact.

Bioassays. For the larvicidal activity assays, third-instar larvae of Aedes aegypti were used. These were obtained from a cyclic colony that has been maintained for more than 10 years at the Institute of Tropical Pathology and Public Health, Federal University of Goiás, at a temperature of $28 \pm 1^{\circ} \mathrm{C}$, relative humidity of $80 \pm 5 \%$ and light and dark cycles of $12 \mathrm{~h}^{18}$. Each fraction containing test compounds was weighed, dissolved previously in dimethylsulphoxide (DMSO), and the volume was made up with distilled water to obtain a stock solution $(500 \mathrm{ppm})$. The non-lethal concentration of DMSO that was used to prepare the solutions was determined previously, in experiments with Aedes aegypti larvae, to be $16.2 \%$ (v/v). From the stock solution, a series of dilutions was prepared in order to obtain the desired concentrations. The bioassays were carried out as five replicates in a climate-controlled environment similar to that of the colony. Twenty third-instar larvae of Aedes aegypti were placed in a $25 \mathrm{ml}$ test solution. Control assays were conducted using the same number of larvae in a DMSO-distilled water solution. The larva mortality after $24 \mathrm{~h}$ was recorded. Total absence of larval movement as well as dark body color and cephalic capsule were used as indicative of death. The lethal concentrations and their respective confidence intervals were calculated by data interpolation, by means of Probit analyses using the Statistical Analyses System (SAEG).

\section{RESULTS AND DISCUSSION}

Liquid-liquid partition of Copaifera reticulata oil-resin $(186.5 \mathrm{~g}$ ) resulted in $162.3 \mathrm{~g}$ of hexane extract and $22.8 \mathrm{~g}$ of methanol extract, which both showed larvicidal activity against Aedes aegypti. The bioassay-guided fractionation of these extracts produced eight fractions for each one. Two hexane $\left(\mathrm{CRH}_{1}, \mathrm{CRH}_{5}\right)$ and two methanol ( $\left.\mathrm{CRM}_{1}, \mathrm{CRM}_{5}\right)$ fractions showed the highest toxicity against Aedes aegypti larvae. The lethal concentrations (LC), with their respective confidence intervals, are shown in Table 1. There was no mortality in the control group.

The results showed that the two fractions $\mathrm{CRH}_{1}\left(\mathrm{LC}_{50} 2.3 \mathrm{ppm}\right)$ and $\mathrm{CRM}_{1}\left(\mathrm{LC}_{50} 0.8 \mathrm{ppm}\right)$ are more active than the oil-resin $\left(\mathrm{LC}_{50}\right.$ 8.9ppm) (Table 1). The two fractions $\mathrm{CRH}_{5}\left(\mathrm{LC}_{50} 13.9 \mathrm{ppm}\right)$ and $\mathrm{CRM}_{5}\left(\mathrm{LC}_{50} 10.5 \mathrm{ppm}\right)$ were slightly less active. Examination of these fractions by TLC and ${ }^{1} \mathrm{H}$ NMR showed their terpenoid nature and GC/MS analysis (NIST library) verified that they

Table 1 - Chemical constituents of the fractions obtained from Copaifera reticulata and their activity against third-instar larvae of Aedes aegypti, after 24 of exposure.

\begin{tabular}{lcrr}
\hline Fractions & Chemical class & $\mathrm{LC}_{50}(95 \% \mathrm{CI}) \mathrm{ppm}$ & $\mathrm{LC}_{90}(95 \% \mathrm{CI}) \mathrm{ppm}$ \\
\hline Oil-resin & & $8.9(6.9-10.8)$ & $59.4(41.9-102.2)$ \\
$\mathrm{CRH}_{1}$ & monoterpenes & $2.3(0.9-3.4)$ & $8.8(7.3-11.5)$ \\
$\mathrm{CRH}_{4}$ & sesquiterpenes & $22.6(22.5-26.4)$ & $43.9(40.2-49.1)$ \\
$\mathrm{CRH}_{5}$ & sesquiterpenes & $13.9(11.2-15.3)$ & $40.9(34.5-52.4)$ \\
$\mathrm{CRM}_{1}$ & mono-, di-, sesquiterpenes & $0.8(0.01-2.5)$ & $8.1(7.9-11.9)$ \\
$\mathrm{CRM}_{3}$ & diterpenes & $17.3(15.3-19.1)$ & $61.1(50.4-80.3)$ \\
$\mathrm{CRM}_{4}$ & diterpenes & $15.5(11.8-18.6)$ & $93.1(67.2-163.0)$ \\
$\mathrm{CRM}_{5}$ & diterpenes & $10.5(9.1-11.7)$ & $21.4(18.6-26.5)$ \\
\hline
\end{tabular}

95\% CI - confidence interval at $95 \%$ probability

$\mathrm{LC}_{50}$ - lethal concentration required to kill $50 \%$ of the population exposed

$\mathrm{LC}_{90}$ - lethal concentration required to kill $90 \%$ of the population exposed

ppm - parts per million 
consisted of monoterpenes and sesquiterpenes. $\mathrm{CRH}_{1}$, which is rich in monoterpenoids that are mainly from the pinane and para-menthane groups, was four times more active than the oilresin. $\mathrm{CRM}_{1}$, which was 11 times more active than the oil-resin, consisted mainly of sesquiterpenoids from the caryophyllene, bisabolane, cadinane and copaene groups. It was refractioned to give, among other subfractions, $\mathrm{CRM}_{1-4}$ with an $\mathrm{LC}_{50}$ of $0.2 \mathrm{ppm}$ and an NMR spectrum that confirmed the presence of sesquiterpenoids (Table 2). $\mathrm{CRM}_{5}$ was rather less active than the oil-resin and, on further fractionation, gave the subfraction $\mathrm{CRM}_{5-7}$ with an $\mathrm{LC}_{50}$ of $0.8 \mathrm{ppm}$, such that the TLC and NMR $\left({ }^{1} \mathrm{H}\right.$ and $\left.{ }^{13} \mathrm{C}\right)$ data showed the presence of clerodane and labdane diterpenoids (Table 2).

Table 2 - Chemical constituents of the subfractions $\mathrm{CRM}_{1}$ and $\mathrm{CRM}_{5}$ from Copaifera reticulata and their activity against third-instar larvae of Aedes aegypti, after 24b of exposure.

\begin{tabular}{lcrr}
\hline Fractions & Chemical class & $\mathrm{LC}_{50}(95 \% \mathrm{CI}) \mathrm{ppm}$ & $\mathrm{LC}_{90}(95 \% \mathrm{CI}) \mathrm{ppm}$ \\
\hline $\mathrm{CRM}_{1-2}$ & monoterpenes & $27.5(12.1-41.9)$ & $>100$ \\
$\mathrm{CRM}_{1-3}$ & monoterpenes & $3.9(2.1-5.5)$ & $37.8(26.6-69.4)$ \\
$\mathrm{CRM}_{1-4}$ & sesquiterpenes & $0.2(0.1-1.2)$ & $12.2(6.1-22.2)$ \\
$\mathrm{CRM}_{1-5}$ & sesquiterpenes & $7.5(4.9-15.7)$ & $65.1(59.4-85.2)$ \\
$\mathrm{CRM}_{1-6}$ & sesquiterpenes & $>100$ & $>100$ \\
$\mathrm{CRM}_{1-7}$ & sesquiterpenes & $>100$ & $>100$ \\
$\mathrm{CRM}_{1-8}$ & labdane diterpenes & $>100$ & $>100$ \\
$\mathrm{CRM}_{1-9}$ & labdane diterpenes & $1.3(0.2-2.5)$ & $>100$ \\
$\mathrm{CRM}_{5-7}$ & labdane diterpenes & $0.8(0.1-1.9)$ & $8.2(6.5-11.3)$ \\
$\mathrm{CRM}_{5-8}$ & labdane diterpenes & $7.9(7.1-8.4)$ & $12.5(11.3-15.1)$ \\
$\mathrm{CRM}_{5-9}$ & furane labdane diterpenes & $32.3(30.4-34.2)$ & $56.2(51.8-62.1)$ \\
$\mathrm{CRM}_{5-10}$ & furane labdane diterpenes & $10.6(9.7-11.5)$ & $21.6(19.4-25.2)$ \\
$\mathrm{CRM}_{5-11}$ & clerodane diterpenes & $6.2(5.7-6.8)$ & $11.1(9.9-13.0)$ \\
$\mathrm{CRM}_{5-14}$ & clerodane diterpenes & $7.3(5.1-9.4)$ & $68.5(48.4-117.2)$ \\
\hline $95 \%$ CI - confidence interval at 95\% probability & \\
$\mathrm{LC}_{50}-$ Lethal concentration required to kill $50 \%$ of the population exposed & \\
$\mathrm{LC}_{90}$ - Lethal concentration required to kill 90\% of the population exposed & \\
Ppm - parts per million & &
\end{tabular}

Summarizing these results, $\mathrm{CRH}_{1}$ consisted mainly of monoterpenoids, $\mathrm{CRM}_{1-4}$ consisted mainly of sesquiterpenoids and $\mathrm{CRM}_{5-7}$ consisted of diterpenoids. These were, respectively, 4.44 and 13 times more active than the oil-resin.

Terpenoids are often reported as candidate insecticides that could be an effective alternative for insect control, with a lower impact on human health, household animals and the environment ${ }^{25}$. The terpenoids reported from Copaifera reticulata oil-resin were much more active than the terpenoids reported in the literature. For example, the sesquiterpenes $E$-nerolidol, farnesol and nerolidol (the first of these isolated from Myroxylon balsamum and the other two obtained from commercial sources) showed $\mathrm{LC}_{50}$ values of 6.0 , 13.0 and $17.0 \mathrm{ppm}$, respectively ${ }^{23}$. The monoterpene isolated from oil produced by Tagetes minuta was active at concentrations above $40 \mathrm{ppm}^{10}$, and the diterpene isolated from Melantheria albinervia showed an $\mathrm{LC}_{100}$ of $62.5 \mathrm{ppm}^{24}$. Furthermore, a triterpene isolated from Azadirachta indica showed an $\mathrm{LC}_{50}$ of $21 \mathrm{ppm}^{17}$. All of these concentrations were much higher than those observed for fractions of $C$. reticulata oil-resin.
The results described in the present paper suggest that some oil-resin fractions $\left(\mathrm{CRM}_{1-4}\right.$ and $\left.\mathrm{CRM}_{5-7}\right)$ of Copaifera reticulata are comparatively more active against Aedes aegypti larvae. These results encourage the search for new natural larvicides. However, further investigations on larvicidal mechanisms of action and the effects of subfractions on non-target organisms and the environment in general, as well as formulations for improving larvicidal potency and stability, are needed for them to be used in practice as naturally occurring mosquito larval control agents.

\section{ACKNOWLEDGEMENTS}

The authors are grateful to the Brazilian institutions FAPESP, CNPq, CAPES, FINEP and FUNAPE for their financial support.

\section{REFERENCES}

1. Basile AC, Sertie JAA, Freitas PCD, Zanini AC. Anti-inflammatory activity of oleoresin from Brazilian Copaifera. Journal of Ethnopharmacology 22:101-109, 1988.

2. Braga IA, Lima JBP, Soares SS, Valle D. Aedes aegypti resistance to temephos during 2001 in several municipalities in the states of Rio de Janeiro, Sergipe and Alagoas, Brazil. Memórias do Instituto Oswaldo Cruz 99:99-203, 2004.

3. Carvalho LAF, Silva IG. Atividade larvicida do temephos a $1 \%$ sobre o Aedes aegypti (Lin.,1762) em diferentes criadouros artificiais. Revista de Patologia Tropical 28:211-232, 1999.

4. Cascon V, Gilbert B. Caracterization of the chemical composition of oleoresins of Copaifera guianensis Desf., Copaifera duckei Dwyer and Copaifera multijuga Hayne. Phytochemistry 55:773-778, 2000.

5. Cheng SS, Chang HT, Ghang ST, Tsai KH, Chen WJ. Bioactivity of selected plant essential oils against the yellow fever mosquito Aedes aegypti larvae. Bioresource Technology 89:99-102, 2003.

6. Choochote W, Kanjanapothi D, Panthong A, Taesotikul T, Jitpakdi A, Chaitong U, Pitasawat B. Larvicidal, adulticidal and repellents effects of Kaempferia galanga. Southeast Asian Journal Tropical Medicine Public Health 30:470-476, 1999.

7. Ciccia G, Coussio J, Mongelli E. Insecticidal activity against Aedes aegypti larvae of some medicinal South American plants. Journal of Ethnopharmacology 72:185$189,2000$.

8. Corrêa MP. Dicionário das Plantas Úteis do Brasil e das Exóticas Cultivadas Instituto Brasileiro de Desenvolvimento Florestal, Ministério da Agricultura, Brasília, Volume V, 1984.

9. Failloux AB, Ung A, Raymond M, Pasteur N. Insecticide susceptibility in mosquitoes (Diptera: Culicidae) from French Polynesia. Journal of Medical Entomology 31:639-644, 1994.

10. Green MM, Singer JM, Sutherland DJ, Hibben CR. Larvicidal activity of Tagetes minuta (Marigold) toward Aedes aegypti. Journal of the American Mosquito Control Association 7:282-286, 1991.

11. Lima JBP, Cunha MP, Silva RC, Galardo AK, Soares SS, Braga IA, Ramos RP, Valle D. Resistance of Aedes aegypti to orghanophosphates in several municipalities in the State of Rio de Janeiro and Espirito Santo, Brazil. American Journal of Tropical Medicine and Hygiene 68:329-333, 2003.

12. Macoris ML, Andrighetti MTM, Takaku L, Glasser CM, Garbeloto VC, Bracco JE. Resistance of Aedes aegypti from the state of São Paulo, Brazil, to organophosphates insecticides. Memórias do Instituto Oswaldo Cruz 98:703-708, 2003.

13. Monzon RB, Alvior JP, Luczon LL, Morales AS, Mutuc FE. Larvicidal potential of five Philippine plants against Aedes aegypti and Culex quinquefasciatus. Southeast Asian Journal of Tropical Medicine and Public Health 25:755-759, 1994.

14. Park IK, Lee SG, Shin SC, Park JD, Ahn YJ. Larvicidal activity of isobutylamides identified in Piper nigrum fruits against three mosquito species. Journal of Agricultural and Food Chemistry 50:1866-1870, 2002. 
15. Perich MJ, Wells C, Bertsch W, Tredway KE. Isolation of the insecticidal components of Tagetes minuta (Compositae) against mosquito larvae and adults. Journal of the American Mosquito Control Association 11:307-310, 1995.

16. Pinheiro FP, Corber SJ. Global situation of dengue and dengue haemorrhagic fever and its emergence in the Americas. World Health Statistics Quarterly 50:161-169, 1997.

17. Siddiqui BS, Afshan F, Ghiasuddin SF, Navqi SNH, Tariq RM. Two insecticidal tetranortriterpenoids from Azadirachta indica. Phytochemistry 53:371-376, 2000 .

18. Silva HHG, Silva IG, Lira KS. Metodologia de criação, manutenção de adultos e estocagem de ovos de Aedes aegypti (Linnaeus,1762) em laboratório. Revista de Patologia Tropical 27:51-63, 1998.

19. Silva HHG, Silva IG, Lira KS. Adaptação do Aedes aegypti em criadouros artificiais com água poluída. Entomologia y Vectores 6:383-391, 1999.

20. Silva HHG, Silva IG, Santos RMG, Rodrigues Fo E, Elias CN. Atividade larvicida de taninos isolados de Magonia pubescens St.Hil. (Sapindaceae) sobre 0 Aedes aegypti (Diptera, Culicidae). Revista da Sociedade Brasileira de Medicina Tropical 37:396-399, 2004.
21. Silva IG, Santos AH, Ferri PH, Alves RBN, Melo RL, Peixoto L, Silva HHG, Elias $\mathrm{CN}$, Isac E, Lira KS, Camargo MF. Atividade larvicida do extrato bruto etanólico deMagonia pubescens St.Hil. (tingui-do-cerrado) sobre oAedes aegypti (Lin.) em laboratório. Revista de Patologia Tropical 25:51-59, 1996.

22. Silva IG, Zanon VOM, Silva HHG. Larvicidal activity of Copaifera reticulata Ducke oil-resin against Culex quinquefasciatus Say (Diptera, Culicidae). Neotropical Entomology 32:729-732, 2003.

23. Simas NK, Lima EC, Conceição SR, Kuster RM, Oliveira Filho AM. Produtos naturais para o controle da transmissão da dengue - Atividade larvicida de Myroxylon balsamum (óleo vermelho) e de terpenóides e fenilpropanóides. Química Nova 27:46-49, 2004.

24. Slimestad R, Marston A, Mavi S, Hostettmann K. Larvicidal constituents of Melantheria albinervia. Planta Medica 61:562-563, 1995.

25. Viegas Jr C. Terpenes with inseticticidal activity: an alternative to chemical control of insects. Química Nova 26:390-400, 2003.

26. Veiga Jr V, Pinto AC. 0 Gênero Copaifera L. Quimica Nova 25:273-286, 2002.

27. World Health Organization. Dengue/dengue haemorrhagic fever prevention and control. Regional Office for South-East Ásia 1-33, 2003. 